$12-19-2018$

\title{
Comments on Judicial Independence and Impartiality in ISDS: A Paper Prepared for the UNCITRAL Working Group III
}

Gus Van Harten

Osgoode Hall Law School of York University, gvanharten@osgoode.yorku.ca

Pavla Křístková

Osgoode Hall Law School of York University

Follow this and additional works at: https://digitalcommons.osgoode.yorku.ca/all_papers

Part of the Law Commons

\section{Repository Citation}

Van Harten, Gus and Kř́istková, Pavla, "Comments on Judicial Independence and Impartiality in ISDS: A Paper Prepared for the UNCITRAL Working Group III" (2018). All Papers. 327.

https://digitalcommons.osgoode.yorku.ca/all_papers/327 


\title{
COMMENTS ON JUDICIAL INDEPENDENCE AND IMPARTIALITY IN ISDS
}

\author{
A paper prepared for the UNCITRAL Working Group III \\ Gus Van Harten and Pavla Kř́stková ${ }^{1}$
}

19 December 2018

We submit this paper in support of the mandate of Working Group III to consider the possible reform of investor-state dispute settlement (ISDS) for reasons of independence and impartiality. The paper aims to avoid duplicating the Secretariat's note on the topic. ${ }^{2}$

The independence and impartiality gap in ISDS

1. A common justification for investment treaty arbitration, also known as ISDS, is that it advances the rule of law by replacing domestic law and courts with a fair, independent, and impartial process for the resolution of investor-state disputes. ${ }^{3}$ This claim is dubious because the rule of law rests on high standards of fairness, including safeguards of judicial independence and impartiality, in adjudicative decision-making. ${ }^{4}$ It is also problematic because independence and impartiality are essential preconditions for public confidence in the process and outcomes of adjudication.

2. Unfortunately, investment treaty arbitration falls short of this essential requirement for the rule of law. The problem is unique to ISDS in its present form because it uses a type of formally non-reciprocal arbitration in which a class of private parties can challenge the sovereign choices of states and because ISDS arbitrators do not have well-known safeguards of independence and impartiality. The absence of the safeguards might not be a concern if the matters decided in ISDS were relatively minor. Yet the arbitrators often resolve fundamental issues of sovereignty that are hugely significant for the people of a country. ISDS involves the review of legislative, judicial, and policy decisions; it is highly determinative; it allows investors to avoid domestic courts; it leads to state liability for potentially huge sums; it triggers coercive enforcement in other countries; and it may lead to severe losses for investors whose claims fail or who face large costs awards against them. In this critically important context for adjudication, it is a serious concern that safeguards of judicial independence and impartiality have not been embedded in ISDS.

\footnotetext{
${ }_{1}^{1}$ Professor and PhD Student in Law, respectively, at Osgoode Hall Law School of York University, Toronto, Canada. We acknowledge with gratitude the review comments of Sophie Turenne, Fellow in Law, University of Cambridge. 2 UNCITRAL, 'Possible reform of investor-State dispute settlement (ISDS): Ensuring independence and impartiality on the part of arbitrators and decision makers in ISDS' UN Doc. A/CN.9/WG.III/WP.151 (30 August 2018). For reasons available on request, this submission has been prepared outside of the arbitrator-organized Academic Forum that is associated with the Working Group.

${ }^{3}$ e.g. Brower and Steven, 'Who Then Should Judge? Developing the International Rule of Law under NAFTA Chapter 11' (2001) 2 Chicago Journal of International Law 193, 195-7 and 200-2.

${ }^{4}$ Van Harten, 'Investment Treaty Arbitration, Procedural Fairness, and the Rule of Law' in Wälde and Schill (eds.), International Investment Law and Comparative Public Law (2010).
} 
Security of tenure as a core safeguard

3. A core institutional safeguard of independence and impartiality in both domestic and international courts is security of tenure. ${ }^{5}$ For generations, security of tenure has been central to the notion of adjudicative independence from other branches of the state and from powerful private interests. Security of tenure emerged as a response to abuse of power by monarchs and it is a key pillar of the institutional apparatus that has limited and refined modern sovereign power. Combined with other safeguards - including the provision of a set salary for the judge, bars on outside remuneration, and an objective means of case assignment - secure tenure insulates the judge from the appearance of inappropriate pressure on his or her decision-making and, by extension, allows the courts to provide a credible foundation for the rule of law. Without security of tenure, one would naturally ask, where do the judges' financial and career interests lie?

\section{The corresponding inappropriateness of for-profit arbitration}

4. As it stands, ISDS is a one-way process for claims to be brought against the state, where one class (foreign investors) triggers the system by bringing the claims and where the other class (states) is liable to pay awards for violating the treaty. Unlike other situations in which arbitration is used to resolve disputes, the ability to bring claims is non-reciprocal. Thus, the arbitrators - especially those whose careers are intertwined with the ISDS industry - are reasonably seen to have an interest in encouraging more appointments by interpreting the law in ways that assist prospective claimants. However much it is called 'judicial' or a 'court' or 'independent', without the judicial safeguards ISDS will always remain a business and (usually) a career path for those appointed to decide the disputes.

5. To illustrate the concern more specifically, many treaties empower ISDS arbitrators to weed out frivolous claims by foreign investors. Yet the arbitrators all stand to earn substantial income if they allow the claim to proceed. In some cases, arbitrators have billed for millions in fees or overseen a complex series of rulings that increased litigation costs substantially. Fundamentally, when public funds and public policy are at stake, there should be no connection at all between the profit motive of adjudicators and the outcome of the cases they decide. The fact that profit is potentially at play in many if not all aspects of ISDS arbitrator decision-making presents a serious challenge for its credibility.

The ISDS arbitration industry

6. The ISDS arbitration industry consists of legal professionals who carry out their challenging role, one assumes, in good faith and with dedication and skill. Yet for the present topic this contribution is largely beside the point. In a for-profit context of adjudication, the economic interests of the arbitration industry and its members are inescapably relevant to the credibility of the process and to

\footnotetext{
${ }^{5}$ Ibid.
} 
its outcomes. For example, many arbitrators have long appeared intent on promoting the industry in competition to its main alternatives (courts, contractually-agreed forums, and diplomacy). ${ }^{6}$ Therefore, it is fair to ask whether this promotion of ISDS might also influence their adjudicative choices. ISDS arbitrators likewise can earn lucrative income from activities beyond the adjudicative role, which raises a concern that their decisions as an arbitrator in one case may be influenced by the interests of paying clients in another. Prominent figures in the industry have sat as arbitrators while advising and representing claimants or respondents and while promoting arbitration clauses in investment contracts, treaties, or arbitration rules. ${ }^{7}$ These and other features of ISDS are a recipe for skepticism, especially when there are clear and well-established ways to ameliorate the relevant concerns.

7. Indeed, the design of ISDS raises precisely the kinds of concerns that safeguards of independence and impartiality would dispel by removing judges from the adjudicative marketplace and putting them into a more stable institution. ISDS arbitrators, like anyone, will no doubt vary somewhat in their level of commitment to values of fairness and sensitivity to outside economic influence. ${ }^{8}$ Yet it must be evident to anyone working in the ISDS industry, as to the informed outsider, that the industry only thrives if foreign investors find it worthwhile to bring claims and if powerful states see benefit in maintaining the system. ${ }^{9}$ This situation creates a credible risk of bias in matters that are often of great importance to a country, such that ISDS does not deliver judicial independence and impartiality.

The power of executive officials in the adjudicative process

8. A further issue arising from the lack of judicial safeguards is the role of the organizations designated as ISDS appointing authorities under investment treaties. These organizations have key powers in ISDS. They often appoint the presiding arbitrator in the absence of agreement by the disputing parties or where a party (usually the state) has not appointed its own arbitrator. They also play an important role in guiding negotiations between the disputing parties about who to appoint by proposing lists of prospective appointees that the appointing authority appears otherwise inclined to select. In the case of the International Centre for Settlement of Investment Disputes (ICSID), awards are subject to limited review by three arbitrators, all of whom are appointed under the authority of the President of the World Bank. ${ }^{10}$ If a party claims a conflict of interest on the part of an arbitrator, the claim may be resolved by the appointing authority. Some appointing authorities exercise supervisory powers over the arbitration rules or over awards in specific cases.

\footnotetext{
${ }^{6}$ Dezalay and Garth, Dealing in Virtue: International Commercial Arbitration and the Construction of a Transnational Legal Order (1996) 50.

${ }^{7}$ Dezalay and Garth, Dealing in Virtue, 8 (noting the role of repeat players, especially large law firms, in the selection of arbitration institutions and in the appointment of arbitrators); Eberhardt and Olivet, Profiting from Injustice, Report by Corporate Europe Observatory and the Transnational Institute (2012).

${ }^{8}$ Dezalay and Garth, Dealing in Virtue, 70.

9 Mattli, Private Justice in a Global Economy: From Litigation to Arbitration, International Organization (2001) 921-2.

${ }^{10}$ Convention on the Settlement of Investment Disputes Between States and Nationals of Other States (ICSID Convention) (Washington, 18 March 1965; 4 ILM 524), Art 52(3).
} 
9. The key problem here is that executive officials have been given discretionary power over key aspects of the adjudicative process. Safeguards are absent that would otherwise alleviate concerns about executive control, i.e. an objective method of case assignment and the resolution of conflict of interest claims by an independent judicial process. In turn, one may ask whether the appointing authority is sufficiently independent and impartial and whether its power structure reflects a satisfactory balance between interests of different constituencies. As it stands, virtually all of the organizations that act as ISDS appointing authorities have a decided institutional slant in favour of one or more major Western capital-exporting states ${ }^{11}$ and/ or international business. ${ }^{12}$ Absent the usual safeguards, the situation gives rise to perceptions that the interests of a powerful state or a multinational firm, where implicated by the dispute, will affect how the appointing authority exercises its powers.

\section{The case for ISDS depends on the core safeguards}

10. If the aim of ISDS is to advance the rule of law, as is often claimed, then the logical result should be to refer investor-state disputes to an international, regional, or domestic forum that incorporates the usual safeguards of judicial independence and impartiality. Put differently, if one thinks there are sufficiently serious problems with the courts in some countries, it is not logical to replace them with an adjudicative process that omits the judicial safeguards, thus giving rise to new and credible doubts about fairness.

11. The evidence is clear that ISDS lacks the safeguards of judicial independence and impartiality that apply in courts when they resolve similar types of disputes. The need for these safeguards 'follows from the fact that independence is status oriented; the objective guarantees define that status. ${ }^{13}$ While different jurisdictions may implement the standards somewhat differently, the safeguards themselves are widely recognized - as central components of independence and impartiality - by domestic courts, ${ }^{14}$ in statements of international organizations, ${ }^{15}$ and in the foundational documents of international courts and tribunals. ${ }^{16}$ The safeguards do not guarantee purity of mind or complete

\footnotetext{
11 e.g. under the ICSID Convention, Art 38, the President of the World Bank exercises the power to appoint. This official is customarily a nominee of the U.S. Administration who is in turn approved by other major states on the World Bank's Board of Directors.

12 e.g. under treaties that designate the International Chamber of Commerce as appointing authority by allowing investors to bring claims under the ICC arbitration rules.

${ }^{13}$ Reference re Remuneration of Judges of the Provincial Court [1997] 3 SCR 3, para 111-112; R v Valente [1985] 2 SCR 673, para 22.

${ }^{14}$ Russell, 'Toward a General Theory of Judicial Independence' in Russell and O'Brien (eds.), Judicial Independence in the Age of Democracy (2001) 1.

15 UN Basic Principles on the Independence of the Judiciary (adopted by the Seventh United Nations Congress on the Prevention of Crime and the Treatment of Offenders, Milan, August 26 - September 6, 1985; endorsed by GA Res 40/32 and 40/146, UN GAOR, 40th Sess, UN Doc A/RES/40/32 and A/RES/40/146 (1985)), art 2 and 11-15.

16 e.g. Convention for the Protection of Human Rights and Fundamental Freedoms (4 November 1950), art 21-3; Treaty of Rome (25 March 1957), art 223 and Statute of the European Court of Justice (March 2008), art 4; Rome Statute of the International Criminal Court (17 July 1998), art 35-6, 40, and 46; Statute of the International Court of Justice (26 June 1945), art 13(1), 16, and 18(1); WTO Dispute Settlement Understanding, art 17(2). Mackenzie and Sands, 'International Courts and Tribunals and the Independence of the International Judge' (2003) 44 Harv ILJ 271.
} 
freedom from inappropriate bias on the part of judges, of course. ${ }^{17}$ However, they are widely accepted as preconditions for the removal of unacceptable risks of perceived bias. ${ }^{18}$

12. Due to this institutional inadequacy of ISDS, it is unnecessary to inquire further into questions of actual bias in ISDS. The institutional deficiencies alone are fatal to claims that ISDS satisfies judicial standards. The situation is especially troubling for final adjudicative decision-making on the legal boundaries of sovereign authority and on awards of potentially huge amounts of public funds to private actors. Yet ISDS promoters sometimes deny that there is no problem with independence in ISDS on the basis that there is insufficient proof of actual bias. This argument rests on a mischaracterization of the standards that apply to adjudicators in general. Rarely if ever is it required that actual bias must be established to disqualify an adjudicator or the institutional context in which he or she adjudicates (although actual bias would of course suffice to disqualify). Instead, one speaks of the absence of an unacceptable 'apprehension' or 'appearance' or 'suspicion' or 'danger' of bias ${ }^{19}$ to recognize that the absence of actual bias alone is not enough.

\section{The issue of evidence of actual bias}

13. By raises the issue of actual bias or non-bias, and the evidence to support one or the other phenomena, ISDS promoters re-direct the debate to questions that are unanswerable. For example, it is sometimes said that claimants in ISDS are frequently unsuccessful and that, even when the claimant wins, the claimant usually receives only a part of the compensation that was originally sought. Yet it is practically impossible to determine conclusively whether claimants or states, or particular claimants or states, would be more or less likely to succeed in a court-based model than in arbitration. Likewise, it is essentially impossible to establish whether important issues - such as the availability of forum-shopping, the scope of the substantive standards of foreign investor protection, or the degree to which deference should be shown to other institutions - would be resolved differently by judges as opposed to arbitrators.

14. Other research may heighten concern about the prospect of actual bias in ISDS. For example, in an analysis of legal determinations by ISDS arbitrators, it was found by one of the present authors that the arbitrators tended to favour the position of claimants when interpreting the treaties. ${ }^{20}$ That is, where arbitrators in the past had adopted an expansive and a restrictive position (i.e. one position that grew the compensatory promise of ISDS for claimants and another that did not), it was found for

\footnotetext{
17 Traynor, 'Judicial Independence: A Cornerstone of Liberty' (2007) 37 Golden Gate University Law Review 487, 492; Larkins, 'Judicial Independence and Democratization: A Theoretical and Conceptual Analysis' (1996) 44 AJCL 605, 613-14; Helfer and Slaughter, 'Why States Create International Tribunals: A Response to Professor Posner and Yoo' (2005) 93 Cal LR $899,904$.

18 Russell, 'Toward a General Theory', 11.

${ }^{19}$ e.g. $R$ v Gough [1993] 2 All ER 724; Reference re Remuneration of Judges of the Provincial Court [1997] 3 SCR 3, para 111-112; Ebner v The Official Trustee in Bankruptcy [2000] HCA 63; [2000] 205 CR 337. Yu and Shore, 'Independence, Impartiality, and Immunity of Arbitrators' (2003) 52 ICLQ 935, 937.

20 Van Harten, 'Arbitrator Behaviour in Asymmetrical Adjudication: An Empirical Study of Investment Treaty Arbitration' (2012) 50 Osgoode Hall Law Journal (2012) 211; Van Harten, 'Arbitrator Behaviour in Asymmetrical Adjudication (Part Two): An Examination of Hypotheses of Bias in Investment Treaty Arbitration' (2016) 53 Osgoode Hall Law Journal 540.
} 
14 generally-applicable legal issues that the arbitrators favoured an expansive position by a ratio of about 3 to 1 . This tendency was present both for substantive issues - such as the definition of 'fair and equitable treatment', 'full protection and security', and 'indirect' expropriation to include investor rights to compensation even for good-faith regulatory change - and for other issues, such as the allowance of claims by minority and indirect owners, the allowance of claims that appeared to overlap with a contractually-agreed forum, and the allowance of claims based on a liberal view of mostfavoured nation treatment that served to avoid limitations on ISDS in the primary treaty.

15. Further, in a keyword-based analysis of ISDS arbitrator reasoning it was found that arbitrators generally did not adopt various means of judicial restraint that are commonly used in courts when reviewing sovereign decisions. ${ }^{21}$ To illustrate, ISDS arbitrators did not discuss and show restraint based on the relative accountability of elected decision-makers, including for states with a strong democratic tradition. They also did not discuss and show restraint based on the relative capacity of governments, whether due to a regulator's specialized expertise or access to information or due to the complexity or sensitivity of the decision under review. They did not defer generally to states or incorporate general limitations as a means to balance investor interests against those of other actors or the collective interest. They proceeded with the adjudication of claims, without otherwise showing restraint, where the investor had resorted to domestic courts or where domestic courts were reasonably available to resolve the claim; where the claimant had agreed to an exclusive jurisdiction clause in a related contract; or where the states parties to the treaty had incorporated a wait period or fork-in-the-road that was not observed by the claimant. Notably, they were found to have used terms typically associated with judicial restraint, such as balancing and proportionality, more often when expanding their authority than when constraining it.

16. Do these studies provide conclusive proof of actual bias in ISDS? Of course not. Like all forms of empirical research into actual bias in adjudication, the findings are and will always be tentative. ${ }^{22} \mathrm{At}$ most, they may heighten concern about the absence of judicial safeguards. Yet the key point is that a debate about actual bias avoids the central issue. The central issue is the undeniable absence of wellestablished safeguards of judicial independence and impartiality in an extraordinarily important context for adjudication. In matters of such importance, the standards and practices that contribute to a culture of judicial independence and impartiality ought to be institutionalized and made explicit.

\section{Research on institutional safeguards in other contexts}

17. As a further guide to the use and importance of institutional safeguards of independence and impartiality in adjudication, we have attached summary findings by Pavla Křístková based on her PhD research, which compares the safeguards in a range of courts and tribunals including ISDS. From this research, it emerged that ISDS has the weakest safeguards among various examples. Also, the

\footnotetext{
${ }^{21}$ Van Harten, Sovereign Choices and Sovereign Constraints: Judicial Restraint in Investment Treaty Arbitration (OUP, 2013) 1612.

22 Sisk and Heise, 'Judges and Ideology: Public and Academic Debates About Statistical Measures' (2005) 99 Northwestern University Law Review 743, 794.
} 
safeguards are more robust not only in courts and tribunals that resolve ISDS-type disputes but also in tribunals that resolve lesser-stakes disputes, i.e. disputes that do not engage the legality of sovereign conduct or lead to potentially huge awards of public compensation to private actors.

\section{The accountability gap in ISDS}

18. Any reform of ISDS should also consider the need for greater accountability in conjunction with greater independence. Accountability requires a reasonable degree of openness to public dialogue and scrutiny. It is necessary simply because power should not go uncontrolled. In court adjudication, various accountability mechanisms serve to counteract the potential perception that the judiciary is just another interest group. The mechanisms also help to address fears that judicial independence could be compromised, e.g. by executive influence over case assignment.

19. Yet in ISDS the current understanding of accountability seem largely restricted to accountability 'from within', in the sense that arbitrators are accountable to disputing parties, practitioners, and other arbitrators as part of a group with shared values, skills, and interests. By comparison, in courts the idea of accountability goes beyond the internal accountability of judges based on appeal and further review. Judges are also expected, as a collective, to deliver justice in a fair, timely, and efficient manner and in accordance with institutional guarantees. The judiciary may also report to legislators on the organization and administration of justice and provide information to the legal community and to the public. Judicially-run complaint mechanisms and disciplinary proceedings supplement a range of other accountability mechanisms. Critically, judicial independence and accountability strengthen each other; one does not come at the detriment of the other. By analogy, stronger accountability mechanisms should also be developed in conjunction with judicial safeguards in ISDS.

\section{Concluding comments}

20. It is suggested that far-reaching reform of ISDS is justified to institutionalize and make explicit the standards and practices that can shape a culture of independence and impartiality. Considering the importance of its dispute resolution function, ISDS should be based on well-established judicial safeguards including security of tenure, a set salary, an objective method of case assignment, prohibitions on outside remuneration, and an independent judicial process to resolve conflict of interest claims. As additional elements of independence and impartiality, it is also recommended that ISDS judges who enjoy the above safeguards should also be authorized to ensure that the rules of ISDS proceedings are fair in the treatment of affected parties and that the proceedings are kept open, in general, in the manner of courts. Mechanisms should also be in place to support greater public accountability of ISDS.

21. Our submission has focused on the reasons for safeguards of independence, impartiality, and accountability in ISDS, with a view to ensuring quality, fairness, and confidence in the international adjudication of important disputes. We hope that the submission is useful to the Working Group. 


\section{ANNEX \\ Excerpts from a Comparative Study of \\ Fairness and Adjudicative Independence and Impartiality in \\ Investor-State Dispute Settlement (ISDS)}

Pavla Křístková23

December 2018

\section{Scope of the Comparative Study}

I devised a comparative study to assess the procedures of ISDS in contrast to reputable adjudicative bodies in various contexts. In the course of this comparison, I examine four categories of legal forums (i.e. domestic courts, European courts, international judicial and quasi-judicial bodies, and international and domestic arbitral tribunals) that are akin to the characteristics and functions of ISDS. I focus on the procedural rules that these forums employ to safeguard shared values of the rule of law including fairness and adjudicative independence and impartiality.

These forums represent the core subject of the study. My aim is to compare procedural rules of the major international arbitral organizations - the International Centre for Settlement of Investment Disputes (ICSID), the Permanent Court of Arbitration (PCA), and the International Chamber of Commerce (ICC) - to the remaining four groups. I have represented the other forums as follows: (1) domestic courts - senior courts of England and Wales and the US Supreme Court; (2) European courts - the European Court of Human Rights (ECHR) and the Court of Justice of the European Union (CJEU); (3) international judicial and quasi-judicial bodies - the International Court of Justice (ICJ) and the World Trade Organization (WTO); (4) domestic and international arbitral tribunals - the Financial Industry Regulatory Agency (FINRA) in the US and the World Intellectual Property Organization (WIPO).

Each forum reflects an adjudicative regime that is comparable to ISDS. Critically, no perfect comparators exist due to ISDS' unique adjudicative features. Accordingly, I did not seek perfect comparators but rather a sample of comparators found within a variety of public and private regulatory systems of adjudication with close connections and/ or similarities. It is impossible to say which group is further afield from ISDS as it depends on the point of reference. From the basic comparison in Table 1, it appears that FINRA and WIPO have the least similarities and that European courts have the most, although it obviously depends on what aspects are compared.

${ }^{23} \mathrm{PhD}$ (Law) Student, Osgoode Hall Law School of York University. 
Table 1: Similarities \& Differences with ISDS

\begin{tabular}{|c|c|c|c|c|c|c|}
\hline ISDS & All & $\begin{array}{l}\text { Vertical } \\
\text { relationship }\end{array}$ & $\begin{array}{l}\text { Based on } \\
\text { treaties }\end{array}$ & $\begin{array}{l}\text { Similar to } \\
\text { judicial review }\end{array}$ & $\begin{array}{l}\text { Use of } \\
\text { arbitration }\end{array}$ & $\begin{array}{l}\text { Number of } \\
\text { similarities }\end{array}$ \\
\hline Domestic courts & Both & Yes & No & Yes & No & 2 \\
\hline European courts & Both & Yes & Yes & Yes & No & 3 \\
\hline \multirow{2}{*}{$\begin{array}{l}\text { International } \\
\text { judicial and quasi- } \\
\text { judicial bodies }\end{array}$} & The ICJ & No & Yes & Yes & No & 2 \\
\hline & The WTO & No & Yes & No & Yes & 2 \\
\hline \multirow{2}{*}{$\begin{array}{l}\text { Domestic and } \\
\text { international } \\
\text { arbitral tribunals }\end{array}$} & FINRA & No & No & No & Yes & 1 \\
\hline & The WIPO & No & No $*$ & No & Yes & 1 \\
\hline
\end{tabular}

*Although the WIPO is based on treaties, disputes between parties are governed by consensual agreements.

Notably, a major difference between the ICJ, WTO, FINRA, and WIPO, on the one hand, and ISDS, on the other hand, is that the former all deal with parties that have horizontal relationships. The ICJ and WTO are state-state adjudicative bodies; FINRA and WIPO deal with horizontal disputes among private parties. In contrast, ISDS deals with vertical relationships between the state and private parties, where the public interest is frequently at stake. In this context, the value of protecting adjudicative independence and impartiality goes beyond two parties in dispute. Moreover, the other bodies that deal regularly with these types of disputes - domestic and European courts - have the strongest protections of adjudicative independence and impartiality. They have permanent adjudicators who are nominated, appointed, and selected for specific cases at different stages of the process, who enjoy security of tenure and stable remuneration, who do not do side work that may conflict with their adjudicative role, who are assigned to cases through a neutral mechanism that spreads workload evenly, and who do not interact with the parties in the determination of their remuneration. These interacting safeguards protect adjudicative independence and impartiality as a basis for public confidence in the institution.

II. Independence and Impartiality: Adjudicative appointment and case assignment

In this section, I examine aspects of procedural mechanisms that aim to secure adjudicative independence and impartiality. Adjudicative independence and impartiality are values of the rule of law and prerequisites to procedural fairness. Adjudicators should decide issues according to the law and facts, without any interference or favoritism for whatever reason from either appointing or assigning authorities. ${ }^{24}$ Independence means freedom from such interference. Various tools have been devised to safeguard adjudicative independence and impartiality, such as security of tenure, set remuneration, separation of powers in the process of adjudicative appointment, and objective methods of case assignment including the separation of methods of appointment from case assignment. These mechanisms are often intertwined and support adjudicative independence and impartiality as common

\footnotetext{
24 Project on International Courts and Tribunals, The Burgh House Principles on the Independence of the International Judiciary
} (2004) at para 1.1. 
and cumulative goals. In this section, I concentrate on the latter: adjudicative appointment and methods of case assignment. I examine security of tenure and remuneration in the next section.

\section{A. Domestic courts}

In the case of examined domestic courts - which like ISDS address vertical relationships between private parties and the state - all use lists of permanent adjudicators. Their appointment processes have several phases: nomination, selection, and appointment. Powers to appoint are dispersed among various actors and each phase is decided by a different set of decision-makers, commonly from outside of the judiciary. In practice, this means that actors with powers to nominate are different from those who assess and select. The latter are typically also different from those who ultimately appoint the approved candidate. As such, in the process of appointment, the power is divided so as to guarantee separation of powers and prevent ill-motivated appointments.

Also, all of these domestic courts deal with case assignments internally. This function is clearly separated from the process of adjudicative appointment to the court. All prescribe a neutral mechanism of case assignment from the lists of permanent adjudicators. Case assignment is done on rota basis using a ticketing system or requires a sitting of the full Court. All bodies also possess discretionary powers to adjust case assignment beyond the normal mechanisms to retain flexibility.

\section{B. European courts}

Both of the European courts examined have permanent judges. The appointment process of these judges is in both courts done in phases, with powers of appointment dispersed among various actors external to the courts. The Member States select their candidates with help from an external body, either the Council of Europe or a designated panel of persons of recognized competence set up by the Council of European Union. The adjudicative appointment is then done either by the Parliamentary Assembly or by common accord of the governments of the Member States.

This process of appointment is clearly separated from the mechanics of case assignment. Case assignment is dealt with by the courts internally. The process is complex but once again similar in both courts. At the initial stage, judges are allocated to chambers and cases are then allocated to these chambers by the whole court. In each chamber, there are judges who sit in every case, such as the President of the Chamber, while the remaining judges are allocated to cases via rotas. In these courts the case assignment methods differ in subtleties. They range from rotation and drawing of lots, at the ECHR, to drawn lists and a use of forms of rotation (with selection following the order of these lists alternated by reverse order) at both courts of the CJEU. This separation and multiplicity of steps safeguards independence and impartiality by preventing judges from being selected for cases in which they might have an interest and by preventing parties from interfering with such selection. 


\section{International courts and tribunals}

The ICJ and WTO tribunals resolve state-to-state disputes rather than vertical disputes. In the case of the ICJ and the WTO Appellate Body, both have permanent adjudicators. Appointments of these adjudicators are done in various stages - nomination, selection, and appointment - with individual tasks vested in different decision-makers and independent of the parties to a dispute. However, there are some variations among these processes. The process of adjudicative appointment to the ICJ is in majority done by external decision-makers. In contrast, although divided to different actors, the WTO process is exercised in majority by the WTO's own decision-makers. Despite this fact, the separation of powers is maintained as, nominations are made by member states or national groups, whereas selection and appointment are done by other decision-makers. Thus, the risk of political pressure in the process of appointment is reduced by distributing powers among different bodies.

Further, at both bodies, the method of case assignment is dealt with internally and clearly separated from adjudicative appointments. ICJ chambers are elected by secret ballot and majority vote. The three out of seven members of the WTO Appellate Body panelists are selected by random rotation. As such, at the ICJ and WTO Appellate Body, the risk of a pressure from appointing bodies is reduced to a single occasion in the course of appointment.

In contrast, whereas at the WTO Appellate Body these practices are mandatory, at WTO panels they are voluntary. WTO panels have their own database of adjudicators which is used as an indicative list only. Thus, a WTO panel can be appointed from outside of the list, which in practice allows the appointment process to be merged with case assignment. Although the panel is constituted ad hoc, adjudicative independence and impartiality are safeguarded by the presence of a higher-ranking Appellate Body - with its permanent members and case assignments by rotation - to which panel decisions can be appealed.

\section{Other arbitral bodies}

The arbitral bodies of FINRA and WIPO are distinguishable from ISDS in that both deal with horizontal disputes arising from commercial disputes between private parties. Both of these bodies use databases of quasi-permanent but untenured arbitrators. Appointment to these databases occurs in several stages: application or nomination, selection, and finally appointment to specific cases. Each occurs independently from the parties to a dispute and, in each phase, there are different decision-makers. The actors with the power to nominate are different from those who assess, select, and finally appoint the candidate. FINRA nominations based on applications by candidates are done by entrusted adjudicators, a first review is carried out by FINRA, and final approval is made by the National Arbitration and Mediation Committee (NAMC). Similarly, at WIPO candidates apply directly or the WIPO Centre may nominate them on its own initiative. The applications are then considered by a special committee, which chooses the members of the WIPO List of Neutrals.

As a default, FINRA's case assignment - based on randomly-generated lists - is dealt with internally and is separated from adjudicative appointment. In contrast, WIPO respects parties' choice and uses its list- 
procedure as a default when parties fail to agree or to appoint. Both bodies also enable parties to appoint arbitrators from outside of the lists. For FINRA, this option, whereby parties can select their own arbitrators, is the only exception from the separation of processes of appointment and case assignment, whereas in the context of WIPO the process of appointment is merged with case assignment. Appointments and workload at both bodies are distributed unevenly. Both bodies also have discretionary powers to arrange assignments out of these mechanisms to retain flexibility.

\section{E. ISDS}

In the arbitral bodies of ISDS, the arbitration rules determine who has the power to select and appoint arbitrators to specific disputes where the parties fail to agree or to appoint. The rules of ICSID, the PCA, and UNCITRAL provide default procedures when parties fail to agree on the number of arbitrators and procedures for their selection. All of these rules prescribe a list-procedure or a ballot. The ICC rules are different in that they empower the ICC Court to make the appointment directly.

Thus, none of these organizations has a permanent list of panel members. All of the ISDS arbitral bodies - ICSID, the PCA, and the ICC - have a panel of arbitrators, members of the court or a database of arbitrators, but the procedural rules do not require that individual arbitrators should be selected from the respective list. Disputing parties, party-appointed arbitrators or the appointing authorities are free to choose arbitrators as they wish. In this regard, the only appointing authority that must choose from a list of panel members is the Chairman of the ICSID. Since the lists of ISDS arbitrators are only indicative, there is no equally spread workload or guaranteed appointments among individuals on any of the lists. The system works in such a way that some individuals may never be appointed.

Case-by-case appointment is the norm for all of these bodies, meaning that the process of adjudicative appointment is merged with case assignment. Due to the lack of separation, powers to appoint an arbitrator and then subsequently to assign him or her to a case are not dispersed. In general, the selection is made by parties or by executive officers (the Chairman of the ICSID Administrative Council and the Secretary-General of the PCA). At the ICC Court, where it acts as the appointing body, the selection is made by a Special Committee created for this purpose; more typically, when the disputing parties each select an arbitrator, these arbitrators then choose the presiding arbitrator.

This practice of case-by-case appointment - with powers vested in the disputing parties and executive officials - raises a concern of potentially inappropriate pressure on arbitrators. The separation of the process of adjudicative appointment from case assignment helps to shield adjudicators from this risk. The ISDS administering bodies however allow a direct link between the appointing authority and the adjudicator in each case. Thus, the appointing (or potentially appointing) officials can directly influence who is assigned to adjudicate. Also, by the nature of these systems, none of these appointing bodies and the associated rules use neutral mechanisms of case assignment such as rotation or random selection from a list of permanent adjudicators. Workload among members of the indicative lists is starkly uneven. 


\section{F. Comparative comments}

In comparison to other bodies, the appointment and case assignment processes in ISDS lack several levels of institutional safeguards. The absence of these safeguards may influence public perception and raises questions about independence and impartiality. Along these lines, some commentators argue that selection on a case-by-case basis may put inappropriate pressures on arbitrators linked to their prospects for future appointment. ${ }^{25}$ Arbitrators who are selected case-by-case may feel a need to adjust their behavior and decisions in ways that are expected to increase their chances of re-appointment. ${ }^{26}$ Further, unlike the state-state and arbitral bodies examined above, ISDS is a vertical arrangement in which only investors can initiate ISDS. The system thrives only if investors see it as favorable. As a result, arbitrators may feel a need to adjust their actions to the needs of investors as 'buyers' of their services.

Some arbitrators oppose these claims and point to their reputation for integrity as evidence of their independence and impartiality. Yet these statements reinforce the critique in that arbitrators, unlike judges, have a need to preserve their 'reputation' in order to be re-appointed. The word reputation raises the question of what kind of reputation arbitrators have in mind since the word can have a different connotation for different stakeholders. In addition, Eberhardt and Olivet claim that arbitrators may feel pressure from among their own tight-knit community of arbitrators, who exert immense influence over the investment arbitration system. ${ }^{27}$ They argue that such a tight-knit community requires arbitrators to act in certain ways to preserve the hope of future appointments. ${ }^{28}$ Breaking with this tight-knit community by independent judgment that is opposed to the mainstream ideology could mean that arbitrators do not get further appointments. ${ }^{29}$

In summary, the structure of ISDS for all of the examined ISDS contexts does not give adequate guarantees to secure independence and impartiality. A lack of separation of powers arises from the merging of appointment and case assignment processes. This issue is exacerbated by the absence, in some cases, or insufficiency of objective methods of case assignment. These aspects create an environment of potential threat to independence and impartiality and an impression that these core values are inadequately protected. Despite claims that ISDS is neutral and apolitical, it is ultimately governed by the will of those with the power to decide who, in the case of ISDS, are not insulated from those with the power to appoint.

\footnotetext{
25 Dalhuisen, Additional Opinion in Compañía de Aguas del Aconquija SA and Vivendi Universal SA v Argentine Republic (2010), ARB/97/3 (International Centre for Settlement of Investment Disputes) para 25.

${ }^{26} \mathrm{Ibid}$. Dalhuisen criticized practices of ISDS arbitrators in seeking re-appointments as an issue related to adjudicative independence.

${ }^{27}$ Eberhardt and Olivet, Profiting from injustice: How law firms, arbitrators and financiers are fueling an investment arbitration boom (2012) at 35-43.

28 Ibid.

29 lbid at 37.
} 


\section{Personal securities - tenure and remuneration}

Security of tenure and financial security are elements of the personal security of adjudicators. They are regarded as interconnected and essential conditions of adjudicative independence and impartiality. ${ }^{30}$ They help to detach adjudicators from linkages with the appointing authorities and to provide 'freedom from external pressure, regardless of the source'. ${ }^{31}$ External pressure can come from various sources, such as appointing authorities, other adjudicators, governmental officials, the public, pressure groups, parties to the dispute, other branches of government, etc. ${ }^{32}$ While security of tenure provides adjudicators with freedom from external pressure, adequate remuneration gives them freedom from financial repercussions and uncertainties. ${ }^{33}$ In other words, security of tenure and remuneration support each other by providing a set of stable and repetitive incomes over the term of tenure. Both safeguards enter the picture of adjudicative proceedings immediately after the completion of the appointment process. When used, they are in place well before any specific dispute is initiated. As such, they form an essential background for fairness in dispute settlement.

In this section, I assess whether and in what form personal security is granted to adjudicators by ISDS in comparison to other adjudicative regimes. I map the use of security of tenure and methods of financial security. With respect to the latter, I assess whether the relevant methods adequately safeguard independence and impartiality. Although the adequacy of remuneration can be assessed by reference to the amount of compensation paid, including all emoluments received, I do not seek to evaluate this aspect. Rather, I focus on whether the methods provide stable financial remuneration that does not turn on the peculiarities of individual cases. That is, I examine remuneration from the perspective of qualities of stability and protection from scarcity, instability, or fluctuation. Accordingly, I am concerned with the general terms of remuneration, such as whether a basic salary is guaranteed, whether the salary is based on a scale or calculated ad hoc, whether the salary depends on performance, whether the salary is protected against reductions, whether there are other emoluments, and whether there is financial security beyond the terms of present service and as a part of the remunerative scheme.

\section{A. Domestic Courts}

The highest courts in the UK and the US employ similar safeguards. Senior judges have secure tenure and cannot be removed from office except for particularly serious misconduct. In both countries the retirement age is 70 , with some exceptions. In terms of remuneration, salaries are based on legislated scales that are annually adjusted. To protect against uncertainties, these annual adjustments cannot lead to a reduction of salaries. Judges in both countries are protected by pension schemes and receive other benefits, e.g. allowances or a federal insurance scheme. While almost all of the features so far have been nearly identical, the pension amount for senior judges varies substantially between the two countries. In the UK, eligible senior judges receive half of the last annual salary whereas in the US they receive an

\footnotetext{
${ }^{30} R v$ Valente, [1985] 52 OR (2d) 779; 24 DLR (4th) 161 at 161; 2 SCR 673 at 675.

${ }^{31}$ Barak, The Judge in a Democracy (2006) at 78-80.

32 Ibid at 78.

$33 \mathrm{lbid}$ at $78-80$.
} 
amount equal to the last annual salary. Due to the use of scaled salaries, the peculiarities of proceedings - especially their length - do not affect the amount of remuneration. This mechanism acts as a prevention against potential conflicts of interest.

\section{B. European courts}

The ECHR and CJEU employ similar personal safeguards. Both protect their judges by security of tenure, although the terms differ. The ECHR affords 9 years of a non-renewable term or service until the age of 70; the CJEU affords a renewable six-year term. During the term, dismissal is possible only if the judge no longer fulfills the requirements of the office. This condition is identical for both courts. However, the specific conditions for removal differ in that the ECHR requires a vote of two-thirds of all judges while the CJEU requires a unanimous peer vote.

Both courts provide guaranteed remunerative schemes that include salaries, other emoluments, and a pension. In each case, the amount is decided by the executive branch; respectively, the Council of Europe or the Council of the European Union. Salaries are set by resolutions or regulations of the appropriate council and based on prescribed scales and annual adjustment. Both courts provide a pension scheme for those who complete an appropriate length of service or reach the required pensionable age. The pension is also calculated according to a scale and in both cases it cannot exceed 70 percent of the last annual base salary. Although the calculation of remuneration is complex, its individual components are generally publicly available. Because of these elaborate protections, remuneration is not dependent on peculiarities of individual proceedings.

\section{International courts and tribunals}

At the ICJ and WTO, the personal securities for adjudicators vary. The strongest level of protection is provided by the ICJ, where judges have security of tenure with a possibility of re-election, a stable base of annual salary which cannot be decreased during the term, and paid allowances and travel expenses. After leaving the court, ICJ judges receive future personal financial security through a pension set at half of the base salary. This personal protection gives judges a peace of mind about their future which means less space for improper influences from outside sources. Due to the method of prescribed sets of base salaries, peculiarities of the proceedings, such as the length, do not influence the amount of judges' remuneration.

The WTO's protections are more mixed. While Appellate Body members have secure tenure for four-year terms with a possibility of one renewal, WTO panelists are selected ad hoc from either an indicative list or an external source. Thus, not all WTO adjudicators are protected by tenure, although all of them do get some level of predefined compensation. Appellate Body members get a monthly retainer, daily fees, and travel refunds but are not regarded as full-time employees and are not covered by the WTO pension scheme. They can and frequently do work in the academic or private sectors or as arbitrators for ICSID. Since WTO panelists do not have secure tenure, they are paid daily fees only when appointed. Both governmental and non-governmental panelists are typically engaged in another type of incomegenerating activity. The former panelists work for the governments of WTO Member States; the latter 
work in the academic or private sector. As such, panelists' income from WTO adjudicative activities is only a supplement to other income. The lack of a pension for panelists likewise entails a lack of financial security beyond the terms of present service. In adjudicative proceedings, the WTO protects the independence and impartiality of Appellate Body members by prescribing a maximum length for the proceedings. This practice means that proceedings are not only speedy but also that there is a cap on the daily fees that adjudicators can earn per case. The cap limits the personal incentives of Appellate Body members. There is no such a cap for panels, however.

Thus, the WTO provides some personal protections to Appellate Body members and very little, if any, to panelists. The latter arrangement makes panelists more vulnerable to external pressure. For Appellate Body members, the stronger protections nevertheless do not reach the level of protection provided by the ICJ.

D. Other arbitral bodies

Both FINRA and WIPO do not provide security of tenure. Arbitrators at both bodies have no financial security and are paid ad hoc for disputes they are appointed to decide. At FINRA, arbitrators cannot request further payments from the parties. The ad hoc character of FINRA's remuneration scheme suggests unguaranteed, irregular, and unstable remuneration from the arbitrator's viewpoint. While it is possible that some arbitrators might get frequent appointments, the system of non-tenure is unable to deliver stable and evenly spread workload among all enlisted. Despite this lack of tenure and financial security, FINRA safeguards values of adjudicative independence and impartiality by using fixed fees for set sessions that are paid exclusively by FINRA. This arrangement excludes parties from the remunerative process and limits the dependence of remuneration on the peculiarities of individual proceedings. In other words, there is no direct remunerative link between the adjudicator and the parties and no dependence of fees on the length of proceedings. FINRA also safeguards these values indirectly by using a neutral selection system.

WIPO has also elaborated a system of remunerative schedules and fees. Yet the fact that the scheme allows the length of proceedings to influence arbitrator's fees, which are moreover fixed by the Centre after consultation with the parties and the arbitrator, implies a potential conflict of interest. That implication arises because the arbitrator's income depends on factors that the arbitrator can influence and because of the proximity between the parties and the adjudicators' remuneration. Therefore, while WIPO employs an elaborate system of fees, it does not shield arbitrators from such conflicts. The only protection at WIPO, in terms of personal securities, is the use of fee schedules and, in some situations, caps on fees, which operate to fix the final fees.

FINRA and WIPO deal with cases of private horizontal relations, where parties might seek flexible ad hoc arrangements with, in general, no public interest at stake. For such purposes, the limited personal safeguards may seem acceptable and reasonable. Yet the fact that these bodies are arbitral bodies does not mean that further personal protections should not be used to strengthen adjudicative independence and impartiality. Between the two bodies, FINRA uses stronger protections and works as an example of 
how strong safeguards can be employed by arbitral administering bodies. If the protections work for one arbitral body, with appropriate modifications they can work for others too.

\section{E. ISDS}

None of the ISDS arbitral bodies - ICSID, the PCA, and the ICC - provide sufficient personal security to arbitrators. Due to the ad hoc nature of their appointments, there is no security of tenure for any of the arbitrators. That is so even though some have been put on formal lists of arbitrators or fulfill other institutional roles for which they receive security of tenure. Yet in their capacity as arbitrators they have no link to such tenure.

From this lack of security of tenure comes inadequate financial security in terms of guaranteed, regular, and stable remuneration over the term of office. Arbitrators are remunerated only when appointed in a specific case, for the time spent and expenditure. Thus, remuneration is calculated and paid on ad hoc basis with no pension or other employment benefits. It depends, first, on whether the individual gets appointed and on frequency of the appointments. Frequent re-appointments of a small number of arbitrators implies less frequent appointments for others. Second, the amount of remuneration depends on the rules of individual institutions. The amount varies substantially among the examined bodies and depends on such factors as whether there is a fees cap or not, whether the amount is based on a fixed hourly rate or is calculated based on a scale, the length of proceedings, the amount in dispute, etc.

According to 2016 study, ISDS brought substantial benefits to the legal industry in arbitrators' fees and other litigation costs. ${ }^{34}$ Another study reported average fees for three-arbitrator tribunals of US\$ 1.28 million per case, making for an average fee per arbitrator of about US\$ 426,500. ${ }^{35}$ Not all fees are public, however, such that this figure accounts for only about two thirds of surveyed cases. ${ }^{36}$ Notably, this average fee exceeds the annual base salary of, for instance, judges at the ICJ and the UK Supreme Court. ${ }^{37}$ Without further information on the length of proceedings for which the amount is paid and on the number of cases in which each arbitrator sat, it is not possible to determine the effective salary of individual arbitrators.

The significance of arbitrator remuneration is relative since it depends on whether the arbitrator has other sources of income. In some cases, the arbitrator's fee is a question of one's livelihood. In others, it will be additional income beyond one's regular salary from work in the private sector, as a judge, as a government official, or as an academic. Salaries in these other occupations obviously differ substantially. For example, arbitrators who work in private practice and receive high levels of remuneration there may see work for

\footnotetext{
${ }^{34}$ Van Harten and Malysheuski, "Who Has Benefited Financially from Investment Treaty Arbitration? An Evaluation of the Size and Wealth of Claimants" Osgoode Legal Studies Research Paper No 14/2016 at 2 and 12-13.

35 Gaukrodger and Gordon, "Investor-State Dispute Settlement: A Scoping Paper for the Investment Policy Community" OECD Working Papers on International Investment 2012/03 at 19; Bernasconi-Osterwalder and Brauch, "Is "Moonlighting" a Problem? The role of ICJ judges in ISDS" IISD Commentary (2017) at 3.

36 Ibid at 19.

${ }^{37}$ The base salary of ICJ judges in 2016 was US\$ 172,978; for UK Supreme Justices in 2017-2018 it was GBP 217,409.
} 
some arbitral bodies as effectively pro-bono, while others may see it as generous additional income. ${ }^{38}$ These facts suggest that the existence of additional sources of income may play a key role in whether the remuneration is a significant incentive or not.

Notwithstanding the potential considerable amounts that an arbitrator may receive, it remains the case that such remuneration is insecure due to its ad hoc nature. First, the lack of tenure creates pressure for arbitrators to secure and compete for appointments. Second, the workload among arbitrators cannot be allocated evenly. Instead, the system creates groups of arbitrators according to the frequency of their appointments: those appointed often, seldom, and never at all. Third, the lack of tenure means that arbitrators have no financial security. The scheme offers no financial protection to cover subsistence during a term of service or beyond. Fourth, insecurity may lead to fear and make arbitrators vulnerable to pressure to secure sufficient income in creative ways. Fifth, arbitrators have a personal stake in the cases that they adjudicate based on the incentive to secure more ad hoc income. This financial stake in disputes can create conflicts of interest. Fifth, all of the examined contexts for ISDS, albeit to different degrees, allow arbitrators to participate in the calculation of their fees. Seventh, without stability and predictability of income, arbitrators may have financial incentives to prolong proceedings to increase their immediate income. Eighth, the fact that fees are paid by, and sometimes negotiated with the parties creates a direct link between arbitrators and the parties whose interests are adjudicated, with a potential for inappropriate influence. For these reasons, it is questionable whether these arrangements for remuneration satisfy basic principles of protection at the heart of adjudicative independence and impartiality.

\section{F. Concluding comments}

My findings show that secure tenure is granted in all domestic, European, and international courts. The only differences lie in the term of office and whether it is renewable. The examined courts apply periods of tenure ranging from 6 years (CJEU; renewable) to 9 years (ICJ; renewable and ECHR; non-renewable) to a prescribed retirement age (UK and US courts). Security of tenure goes hand in hand with financial security. In the examined domestic and European courts, remuneration is prescribed by law with the amount in general made public. Typically, the amount is a combination of base salary and other emoluments. Judges receive a set of monthly salary that is reviewed annually. The base annual salaries of all these courts are publicly disclosed, except at the ICJ which has not made its fees schedules public. It is common that annual adjustments cannot lead to a reduction of salary. As a default, base salary does not depend on performance and does not rely on particularities in proceedings or their length or the amounts in dispute. In turn, there is no risk that judges will have an incentive to prolong proceedings artificially. Moreover, the disputing parties cannot influence the amount of remuneration to which judges are entitled, thus avoiding any direct link between them and their adjudicator. This arrangement insulates adjudicators from improper influence by a party. The amount received, age of retirement, and years of

\footnotetext{
38 Puig, "Social Capital in the Arbitration Market" (2014) 25 European Journal of International Law 387 at 398 (referring to ICSID).
} 
service differ for individual courts, but all provide remunerative schemes that include a pension. The pension provides a financial security beyond the term of present service.

One point of difference among the examined courts is that, while judges are in general precluded from engaging in external work, at the ICJ some judges frequently sat in ISDS cases. This role brought substantial financial supplements for their fixed remuneration at the ICJ and in practice weakened the ICJ's safeguards of adjudicative independence and impartiality. ICJ judges could also benefit from working less at the court, undermining their apparent dedication to the ICJ workload. ${ }^{39}$ The ICJ is an influential international adjudicative body so there are also implications of this practice for other international adjudicative bodies. This side work could also influence judges' decision-making in cases before the ICJ if they have an interest in ISDS appointments. Similarly, there is a problem with their independence and impartiality if they decide challenges of other co-arbitrators or if they select arbitrators to sit in ISDS who might in future select the ICJ judges as arbitrators. ${ }^{40}$ In light of these issues, it was appropriate to end this practice, as the ICJ recently did. Notably, the ICJ Statute maintains that judges may not 'engage in any other occupation of a professional nature'. ${ }^{41}$

International and domestic tribunals - focusing on the WTO, WIPO and FINRA - use remuneration schemes that differ from courts. However, this divergence can be explained by difference in the work settings of adjudicative bodies. Only the WTO Appellate Body incorporates security of tenure for four years, renewable, although the tenure is different from courts and financial security takes the form of monthly retainer. It is typical that Appellate Body members, as non-permanent employees, do external work in the private sector, academia, etc. Also, the length of Appellate Body and panel proceedings have some impact on daily fees but, for Appellate Body members, this impact is limited by caps on the length of proceedings. For panelists, who lack tenure, the WTO sets moderate daily fees and caps remuneration for expenses. The length of panel proceedings can be lengthier than the Appellate proceedings with a more impact on the panelists' remuneration. Further, both panelists and Appellate Body members as nonemployees are not covered by the WTO pension scheme.

Both WIPO and FINRA have lists of potential arbitrators without granting security of tenure. In both cases, being on the list merely creates a possibility of selection to arbitrate. The remunerative schemes at both bodies is based on the cases that an adjudicator decides. WIPO uses schedules of fees with caps and indicative hourly fees. FINRA has fixed fees per session or based on special tasks. As there is no tenure, there is no permanent employment and corresponding benefits including a pension scheme. The length of proceedings for both bodies has some impact on the amount of remuneration. At FINRA, it is the number not the length of sessions that influences remuneration. Both the WTO and FINRA provide remuneration from their budgets with no option for arbitrators to negotiate higher fees with the disputing parties. WIPO is an exception in that final fees are fixed by the relevant administrative body after

\footnotetext{
39 Bernasconi-Osterwalder and Brauch, above note 35 at 4.

$40 \mathrm{lbid}$ at 5.

${ }^{41}$ Statute of the International Court of Justice, Article 16.
} 
consultation with the arbitrators and parties. Based on these findings, WIPO affords the weakest personal protections for adjudicative independence and impartiality, but for ISDS.

Like WIPO and FINRA, ISDS administering bodies do not provide security of tenure. All ISDS bodies have indicative lists. Some arbitrators act as permanent members of these bodies but their status on the list does not bring any personal security. This ad hoc arrangement creates inequality in the allocation of cases. Even in the event of an appointment, remuneration may depend on the hourly rate, the amount in dispute, the length and complexity of the case, or a mix of these factors. The ICSID daily fee is capped and the lowest among the examined bodies. The PCA requires the fee to be reasonable; as such, the fee can be the same as at ICSID or higher. The ICC uses an elaborate fees schedule with no fees cap. Other than at ICSID, the remuneration of individual arbitrators is frequently confidential. From available data, average fees per case can be substantial. Fees are typically fixed in consultation with the disputing parties and appointing authorities. In addition to ISDS fees, it is a common for ISDS arbitrators to engage in outside work. The lack of tenure and financial stability puts more pressure on arbitrators to secure income to cover their daily expenses and subsistence unless they enjoy such benefits from other work.

Although the high level of remuneration might be a way to compensate for these uncertainties, it remains that only those appointed can benefit in this way. This fact underscores the gap between the most frequently-appointed individuals and those who are not or hardly ever appointed. The resulting pressure to find ways to make more money may seriously undermine public confidence in the arbitrators' independence and impartiality. ISDS arbitrators are more vulnerable to the whims of the 'market' for appointments and more vulnerable to incentives to encourage the boom of the industry, compete with other arbitrators for appointments, and work on longer and more complex proceedings. All of these factors affect how much, if at all, the person can expect to be paid. 